\title{
Digitalisering af universitetets prøveformer
}

Læring og Medier (LOM) - nr. 7/8, 2011 ISSN 1903-248X

\section{Rasmus Blok}

Specialkonsulent, E-læring Aarhus Universitet.

\section{Marie Gottlieb}

Head of Research and Learning Support

IT-Universitetet, København. 


\section{Om temaet: Digitalisering af universitetets prøveformer}

Digitalisering af skriftlige prøver og eksamener - eller rettere manglen på samme - har det seneste år været et 'hot' emne indenfor specielt universitetsområdet og uddannelsesområdet generelt. Således har dagblade og aviser haft emnet under solid behandling, og universiteterne er i særdeleshed blevet beskyldt for ikke at følge med tiden og leve i fortiden, når de endnu ikke tilbød de studerende en digitaliseret adgang til prøver. Politikere og meningsdannere har ikke været sene til at byde ind med meninger, visioner og kritiske kommentarer om uddannelsessektoren håndtering af prøverne, og senest i forbindelse med årets valgkamp fremkom der håndfaste krav om digitalisering af området fra flere kanter.

De er dog kun et lille hjørne af sandheden og emnet generelt, som blev eksponeret for offentligheden og gjort til genstand for debat. Hvad der således igangsatte debatten og forblev dens genstandsområde var de skriftlige sted-prøver på universiteterne, hvor der blev anvendt gennemslagspapir eller hvor de studerende blev bedt om at skrive i hånden. Men selvom denne type eksamen og prøve generelt kun en minoritet af de skriftlige prøver og endnu mindre procentdel af alle prøver ved universiteterne - blev de alligevel fejlagtigt gjort til genstand for hele området i debatten (på AU udgør skriftlige stedprøver under 10 procent af skriftlige prøver og omkring 5-6\% af alle prøver ved universitetet).

Og hvis man går i detaljer, så er det endda kun et fåtal af disse stedprøver (formentlig under halvdelen), som er baseret på det udskældte gennemslagspapir eller håndskrift. Resten af disse stedprøver bliver i dag faktisk afviklet digitalt i en eller anden form. Så mediernes søgelys fokuserede på en meget lille brøkdel af prøverne ved universitetet, og overså desværre den langt overvejende del, hvor kuglepen og gennemslagspapir ikke længere udgør grundlaget.

Der skal herfra ikke herske tvivl om, at redaktørerne af dette tidsskrift på ingen måde er særlige varme tilhængere af prøver og eksamener baseret på håndskrift eller gennemslagspapir - vi er trods alt tidsskriftet for læring og medier (underforstået nyere medier end kuglepen og gennemslagspapir). Sådanne prøver og 
eksamener - uanset deres fătal - trænger langt overvejende til en modernisering - herunder en gentænkning og digitalisering. Når det så er sagt, så er den oplevede overeksponering og fokus på gennemslagspapir ærgerlig i mere end én forstand.

For det første giver det jo selv sagt et fejlagtigt billede af prøveformerne ved universitetet og afsporer grundlaget for en rimelig debat, når 1-2\% af prøverne gøres til grundlaget for alle prøver og eksamener ved universitetet. $0 \mathrm{~g}$ i den henseende er det jo også ærgerligt, at universiteterne fejlagtigt blev miskrediteret for dets håndtering af prøver generelt, når fokus rettelig burde have været på de 1-2\%. For det andet og langt mere ærgerlig er det, at den afsporede debat skyggede for de mange forskelligartede digitaliseringer som allerede er dagligdag på universiteterne indenfor resten af prøveområdet, samt de mange interessante eksperimenter og forsøg som pågår i disse år med digitalisering af alle prøveformerne.

Dette nummer ønsker at råde bod på den skævvredne debat og kaste lys over universiteternes forskelligartede digitaliseringsfors $ø g$ disse år, og som ikke vandt fokus da mediestormen red hen over dem. Dette nummer af Læring og Medier (LOM \#7/8) med temaet "Digital Eksamen" præsenterer således en række artikler og rapporter fra universiteterne med et dobbeltrettet fokus på digitaliseringen af prøver og eksamener. Dels forsøg på at opgradere og digitalisere håndteringen af de eksisterende prøveformer på universitetet og dels forsøg på at nytænke prøveformerne i lyset af de mange nye muligheder som digitaliseringen tilbyder.

Allerførst vil vi gerne ønske vores nye uddannelsesminister tillykke med posten, og samtidigt give Morten Østergaard lejlighed til at udpege sin og den nye regerings vision for universiteterne når det gælder digitalisering af eksamener og prøver. Vi er således glade for, at selv i en hektisk tid, har vi kunne lokke Uddannelsesministeren til at svare på en række konkrete spørgsmål om dette tema. Disse præsenteres i den indledende klumme " 5 hurtige spørgsmål til ministeren".

Rasmus Blok, Mads Stenhøj Andresen og Hans Sommer fra Aarhus Universitet præsenterer i deres rapport "Overgang til digital aflevering og bedømmelse af skriftlige prøver ved Aarhus Universitet og Ingeniørhøjskolen i Århus" et igangværende projekt, hvor al håndtering af de skriftlige prøver digitaliseres. Projektet præmis er 
at undgå udprint, og i stedet holde og bibeholde alle relevante data i et digitalt format, samtidigt med at hele processen understøttes digitalt for både studiesekretær, studerende og bedømmer. Projektets evalueringer peger på en overvejende succes, men der peges også afslutningsvis på rækken af mulige udfordringer som en digitalisering af alle de skriftlige eksamener og prøver kan medføre.

Annette Q. Pedersen fra Københavns Universitet skriver i sin artikel "Implementering af organisatoriske forandringsprocesser - ved indførelse af elektronisk aflevering og eksamen" netop om den række af udfordringer som en digitalisering af eksamensområdet afstedkommer. På baggrund af KUs humanistiske fakultet indførelse af obligatorisk e-aflevering på skriftlige eksamener, opstilles 10 væsentlige råd. Ikke overraskende koncentrerer disse råd sig mindre om de tekniske aspekter, end om de bagvedliggende organisatoriske forandringsprocesser.

Annette Q. Pedersen fra Københavns Universitet supplerer sin artikel med en kort video-præsentation "E-aflevering på Humaniora, København Universitet”, af de mere praktiske omstændigheder omkring indførelsen af elektronisk aflevering. Her fortælles kort om baggrunden for projektet, samt den optik om eksisterende løsninger og lavthængende frugter, som ligger til grund for den valgte løsningsmodel. Løsningsmodellen præsenteres kort og der præsenteres testimonials fra brugerne.

Anja M. Lindelof fra Roskilde Universitet præsenterer med artiklen "Podcast som eksamensform" en nytænkning af den analoge eksamensform. Udgangspunktet er en forståelse af, at det dominerende socialkonstruktivistiske læringsparadigme som naturlig konsekvens bør inddrage digitale medier i undervisningen, men også i evaluering og eksamen. Artiklen bliver derved eksponent for det stigende ønske om at bringe mere sammenhæng (alignment) mellem undervisningen og dens prøveform, som forskning peger på er gavnligt for de studerende læring. Samtidigt viser artiklen på bedste vis, at de nye digitale muligheder (her podcasts) sætter nye betingelser og standarder for hvordan man kan tænke og gennemføre prøver og eksamen ved universitetet.

Annette Grønning fra Syddansk Universitet er en anden underviser, som gennem brug af digitale teknologier forsøger at gentænke og reformulere de klassiske eksamensformer ved universitetet. I sin artikel "E-tiviteter som eksamensform" præsenteres en række e- 
tiviteter, baseret på Gilly Salmons modeller, som alternativ til gængse eksamensformer. Artiklen tager fat i fordele og ulemper heri, men konkluderer på interessant vis også en positive påvirkning den ændrede eksamensform har på selve undervisningen og de studerendes læring. Således påvises øget studentermotivation og øget læringstaksonomi, som konsekvens af den digitale eksamensform.

Christopher Kjær fra Syddansk Universitet samler i temaets sidste artikel "Mundtlig eksamen via Adobe Connect" op på tre års erfaring med brug af digital videokonference som alternativ og ny eksamensform indenfor det mundtlige område. Artiklen indfører først til en række mere tekniske aspekter og præmisser for denne nye eksamensform, samt de gængse begrundelser for denne digitalisering. Afslutningsvis præsenteres og diskuteres en række konkrete cases hvor Adobe Connect er blevet anvendt, og artiklen samler op gennem videregivelse af en række retningslinjer for de som vil give sig i kast med lignende prøveformer.

Udenfor dette nummers tema præenteres en artikel og vores faste juridiske klumme. Lisbet P. Svendsen og Margrethe S. Mondahl fra Copenhagen Business School præsenterer i deres artikel "Tools for teaching the 'Digital Natives'" de udfordringer universitetsundervisningens står overfor, når de studerende tænker og agerer anderledes og langt mere digitalt i dag. Gennem fokus på nytten af socialt software diskuterer artiklen kollaborative og individuelle læringsprocesser, samt deres gavn for de studerendes læringsudbytte. Diskussionen baseres afslutningsvis på sammenligningen af to konkrete cases fra Copenhagen Business School.

Endelig afrundes dette nummer af Læring og Medier med vores faste klumme om e-læring og jura. I klummen "ophavsret til undervisningsmateriale" gennemgår jura-professorer Morten Rosenmeier fra Københavns Universitet, forholdene omkring underviserens rettigheder i forhold til sit undervisningsmateriale og deling af den i regi af universitetet.

Vi håber den nysgerrige læser vil få et mere detaljeret og nuanceret indblik i digitaliseringen af eksamensformerne og prøverne ved de danske universiteter, end den som medierne fremstillede dette år. Samtidigt håber vi også at vores læsere på universiteterne og andre undervisningsinstitutioner her kan finde relevant inspiration til selv 
at iværksætte nye eller udvikle på eksisterende tiltag mod digitale eksamener og prøver.

God læselyst

Rasmus Blok \& Marie Gottlieb 